\title{
Odpowiedzialność kościelnych osób prawnych za czyny pedofilskie duchownego - wyrok na miarę precedensu. Uwagi w sprawie wyroku Sądu Najwyższego z dnia 31 marca 2020 r., sygn. II CSK 124/19
}

\section{Wprowadzenie}

Komentowane orzeczenie ma dużą doniosłość prawną oraz społeczną. Jego ranga wykracza poza rozstrzygnięcie konkretnej sprawy cywilnej o znacznej, wynoszącej ponad milion złotych, wartości przedmiotu sporu. Jest to bowiem pierwsze orzeczenie Sądu Najwyższego (SN) dotyczące odpowiedzialności cywilnej kościelnych osób prawnych za czyny pedofilskie, których dopuściła się osoba duchowna. Dotychczas tego rodzaju sprawy nie trafiały na wokandę SN zwłaszcza z powodów psychologicznych, ale także socjologicznych. Brakowało odwagi i determinacji przede wszystkim po stronie ofiar pedofilii niektórych przedstawicieli duchowieństwa ${ }^{1}$. Nie powinno to jednak dziwić ze

* Paweł Borecki, dr hab., Uniwersytet Warszawski, e-mail: borecki@wpia.uw.edu.pl, https://orcid.org/0000-0002-1921-8291.

${ }^{1}$ Według danych przedstawionych 14 III 2019 r. przez Konferencję Episkopatu Polski przyjęto 382 zgłoszenia przypadków seksualnego wykorzystywania małoletnich, w tym 198 dotyczyło osób poniżej 15. roku życia, a 184 powyżej 15. roku życia; zgłoszone przypadki obejmują czas od 1 I 1990 r. do 30 VI 2018 r. Sekretariat Konferencji Episkopatu Polski otrzymał dane od wszystkich diecezji i zakonów. Zostały one opracowane przez Instytut Statystyki Kościoła Katolickiego i Centrum Ochrony Dziecka. Łączna liczba ofiar we wszystkich, również niepotwierdzonych, przypadkach poniżej 15. roku życia wynosiła 345, natomiast powyżej 15. roku życia - 280. Wśród ofiar we wszystkich zgłoszonych przypadkach małoletni płci męskiej stanowili 58,4\%, a małoletni płci żeńskiej 41,6\% (https://episkopat. $\mathrm{pl} /$ opracowanie-dot-zgloszen-przypadkow-wykorzystania-seksualnego-maloletnich/, 
względu na ich traumatyczne przeżycia, a także socjologiczną dominację katolicyzmu we współczesnej Polsce i duże wpływy Kościoła katolickiego, szczególnie po roku 1989 r. w instytucjach publicznych, m.in. w oświacie. $Z$ czasem nastąpiło przedawnienie wielu spraw. Te okoliczności w połączeniu ze zwykłym oportunizmem powodowały, że zawodowi pełnomocnicy procesowi niejednokrotnie unikali angażowania się w tego rodzaju sprawy. Jednocześnie instytucje kościelne nie wykazywały woli współpracy z organami wymiaru sprawiedliwości $w$ tego rodzaju sprawach ${ }^{2}$. Wręcz przeciwnie, miały miejsce przypadki ich tuszowania ${ }^{3}$. Episkopat Polski jeszcze w 2012 r. odrzucił możliwość wypłaty odszkodowań przez Kościół instytucjonalny w Polsce na rzecz ofiar pedofiliii ${ }^{4}$. Dotychczas stanowisko to nie uległo zmianie ${ }^{5}$. Jako jeden z zasadniczych argumentów na jego rzecz wskazywano, że prawo nie powinno przewidywać odpowiedzialności zbiorowej ${ }^{6}$.

dostęp: 8 VII 2020). Fundacja "Nie Lękajcie Się" odnotowała natomiast przypadki pedofilii w 266 miejscowościach w Polsce na podstawie zgłoszeń samych ofiar.

${ }^{2}$ Dopiero od dnia 13 VII 2017 r. wprowadzony został w wyniku nowelizacji art. 240 Kodeksu karnego (Dz.U. poz. 773) prawnokarny obowiązek niezwłocznego zawiadomienia organu powołanego do ścigania przestępstw o karalnym przygotowaniu albo usiłowaniu lub dokonaniu czynu zabronionego określonego m.in. w art. 200 tego aktu (obcowanie płciowe z małoletnim).

${ }^{3}$ Zob. m.in. Ł. Cieśla, Jest wniosek o przeszukanie poznańskiej kurii. W sprawie molestowania i gzwałtów na byłym ministrancie z Chodzieży, "Gazeta Pomorska” 2020, nr 13, s. 3; ŁK, Abp Gądecki nie wydat dokumentów prokuraturze ws. Janiaka. Teraz będzie wizytatorem w kaliskim seminarium, https://wiadomości.gazeta.pl/7,114883,26082055,abp-gadecki-nie-wydal-dokumentow-prokuraturze-ws-janiaka-teraz.htm\#do_w46\&do_a286\&s=BoxNewsLink (dostęp: 1 VII 2020). Portal OKO.press w maju 2019 r. zarzucił siedmiu polskim biskupom tuszowanie przypadków pedofilii. Są to: Alojzy Orszulik, Andrzej Dziuba, Edmund Piszcz, Wojciech Ziemba, Józef Górzyński, Józef Kupny, Kazimierz Nycz (S. Klauziński, Dziuba, Orszulik, Nycz i inni. Siedmiu biskupów, którzy tuszowali przypadki pedofilii. Śledztwa OKO.press, https://oko.press/biskupi-ktorzy-tuszowali-pedofilie-w-kosciele/, dostęp: 8 VII 2020). Zob. także szerzej: M. Wójcik, Biskupi, którzy kryli księży pedofilów [RAPORT], https://wyborcza.pl/duzyformat/7,127290,24884600,biskupi-ktorzy-kryli-ksiezy-pedofilow-raport.html (dostęp: 8 VII 2020).

${ }^{4}$ Zob. m.in. D. Zalewski, PAP, Bez odszkodowań dla ofiar pedofilii w polskim Kościele - dokument episkopatu, http://wiadomości.gazeta.pl/wiadomości/1.114883.11342994,Bez_odszkodowań_dla_ofiar_pedofilii_w_polskim_Kosciele.htm (dostęp: 1 VII 2020); zob. także: Bez odszkodowań dla ofiar księży pedofilów, https://www.tvp.info/6740983/informacje/ polska/bez-odszkodowan-dla-ofiar-ksiezy-pedofilow/ (dostęp: 8 VII 2020).

${ }^{5}$ Por. Stanowisko Konferencji Episkopatu Polski w sprawie wykorzystywania seksualnego osób małoletnich przez niektórych duchownych, Jasna Góra, 19 XI 2018 r., https://episkopat. $\mathrm{pl} /$ stanowisko-konferencji-episkopatu-polski-w-sprawie-wykorzystywania-seksualnego-osob-maloletnich-przez-niektorych-duchownych (dostęp: 8 VII 2020).

${ }^{6}$ Por. KAI, Chrystusowcy odpowiadaja na petycje w sprawie wycofania skargi kasacyjnej, https://ekai.pl/chrystusowcy-odpowiadaja-na-petycje-w-sprawie-wycofania-skargi- 
Należy przy tym podkreślić, że w omawianej sprawie SN zachował bezstronność, szczególnie w zakresie doboru składu orzekającego. Ze względu na spójne, kompleksowe i logiczne uzasadnienie wyrok z 31 marca 2020 r. ma szanse nabrać w praktyce charakteru precedensu. W innych krajach, zwłaszcza w Stanach Zjednoczonych Ameryki, odpowiedzialność instytucji kościelnych za nadużycia seksualne niektórych duchownych rozwinęła się właśnie na podstawie orzecznictwa sądowego. W Stanach Zjednoczonych liczba tego rodzaju spraw była nad wyraz wysoka, a wypłacone odszkodowania na rzecz ofiar tak duże, że doprowadziło to do ogłoszenia bankructwa niektórych diecezji katolickich. A przy tym sędziowie amerykańscy nie mieli lepszych podstaw prawnych do orzekania niż polski sędzia ${ }^{7}$. Można wręcz powiedzieć, że polski sędzia ma lepsze podstawy prawne do orzekania $w$ tego rodzaju sprawach (art. 415, 416, 429 i 430 Kodeksu cywilnego ${ }^{8}$ ) niż sędzia amerykański i nie ma potrzeby tworzenia jakiejś szczególnej regulacji, która i tak odnosiłaby się tylko do czynów przyszłych'

Sąd Najwyższy komentowanym wyrokiem przede wszystkim oddalił skargę kasacyjną kościelnych osób prawnych zwierzchnich (zakonu - Towarzystwa Chrystusowego dla Polonii Zagranicznej oraz jego właściwego domu zakonnego) wobec duchownego - sprawcy czynów pedofilskich. W skardze kasacyjnej domagano się uchylenia wyroków Sądu Apelacyjnego zasądzającego zadośćuczynienie na rzecz ofiary w wysokości 1 miliona złotych oraz dożywotnią rentę w kwocie 800 zł miesięcznie. Powódka wniosła pozew o ochronę dóbr osobistych: zdrowia, godności i czci ${ }^{10}$.

Sąd Najwyższy podzielił stanowisko Sądu Apelacyjnego, przyjmując za podstawę odpowiedzialności kościelnych osób prawnych w świetle całokształtu okoliczności faktycznych sprawy art. 430 k.c. (wina

-kasacyjnej/ (dostęp: 10 VII 2020). Padały także argumenty o konieczności specjalnej ustawy dotyczącej odpowiedzialności instytucji kościelnych, o rzekomym braku ich zdolności deliktowej.

${ }^{7}$ M. Nesterowicz, Odpowiedzialność cywilna Kościoła katolickiego za molestowanie małoletnich przez księży (prawo USA i prawo polskie), „Przegląd Sądowy” 2014, nr 1, s. 8; A. Sieczych, Odpowiedzialność odszkodowawcza zwiazków wyznaniowych za przestępstwa seksualne duchownych w USA i w Polsce (casus Kościoła katolickiego), „Państwo i Prawo” 2017, z. 1, s. 65-77.

${ }^{8}$ Ustawa z dnia 23 IV 1964 r. - Kodeks cywilny (tekst jedn. Dz.U. 2019, poz. 1145), dalej „k.c.".

${ }^{9}$ M. Nesterowicz, op. cit., s. 8.

${ }^{10}$ Zob. K. Żaczkiewicz-Zborska, SN: Zakon jako zwierzchnik księdza zapłacizadośćuczynienie ofierze, https://www.prawo.pl/zadoscuczynienie-za-przestepstwo-księdza-zaplaci-zakon (dostęp: 22 VI 2020). 
w nadzorze). Przekonująco zdystansował się natomiast od poglądu Sądu Okręgowego (sąd pierwszej instancji), że należy rozważyć także odpowiedzialność na podstawie art. 429 k.c. (wina w wyborze) ${ }^{11}$.

\section{Wybrane przesłanki odpowiedzialności cywilnej kościelnej osoby prawnej}

W uzasadnieniu wyroku Sąd Najwyższy dokonał wnikliwej analizy przesłanek odpowiedzialności cywilnej kościelnych osób prawnych za działalność podległej im osoby duchownej. Stwierdził zwłaszcza, że jeżeli sprawca działa dla korzyści osobistej, a wykonywanie czynności służbowej umożliwia mu wyrządzenie szkody, zwierzchnik nie może skutecznie podnieść zarzutu, że podwładny wyrządził szkodę tylko przy okazji realizacji powierzonych zadań ${ }^{12}$. W istocie rzeczy SN tym samym podtrzymał wypracowaną od lat interpretację art. 430 k.c., zakładającą odpowiedzialność osób prawnych za szkodę wyrządzoną przez podwładnego ${ }^{13}$. Wyraźnie odniósł tę odpowiedzialność do kościelnych osób prawnych ${ }^{14}$.

Dowodząc, że wyrządzenie szkody przez sprawcę nastąpiło przy wykonywaniu powierzonych mu czynności, a nie jedynie przy okazji, Sąd

${ }^{11}$ Jako najważniejsze tezy wyroku należy wskazać następujące konstatacje:

1. Sąd Najwyższy uznał, że związanie prawomocnym wyrokiem skazującym (art. 11 k.p.c.) nie wyłącza poczynienia przez sąd w sprawie cywilnej ustaleń dotyczących okoliczności wyeliminowanych przez sąd karny z opisu czynu zabronionego, wskazujących na popełnienie przez księdza katolickiego przestępstw przy nadużyciu zaufania ofiary, wynikającego z zadań powierzonych sprawcy przez kościelne osoby prawne sprawujące nad nim zwierzchni nadzór.

2. W razie powierzenia przez instytuty zakonne duchownym zakonnym lub zakonnikom czynności służbowych, do odpowiedzialności za szkody przez nich wyrządzone przy wykonywaniu tych czynności ma zastosowanie art. 430 k.c.

3. W świetle art. 430 k.c., jeżeli sprawca działał w celu osobistym (dla korzyści osobistej), a wykonywanie powierzonej czynności służbowej umożliwiło mu wyrządzenie szkody, zwierzchnik nie może skutecznie podnieść zarzutu, że podwładny wyrządził szkodę tylko przy sposobności (przy okazji) realizacji powierzonych zadań (http://www.sn.pl/aktualnosci/SitePages/Komunikaty_o_sprawach.aspx?ItemSI$\mathrm{D}=354-\mathrm{b} 6 \mathrm{~b} 3 \mathrm{e} 804-2752-4 \mathrm{c7d}-\mathrm{bcb} 4-7586782 \mathrm{a} 1315$ \&ListName=Komunikaty_o_sprawach\&rok=2020, dostęp: 20 X 2020).

${ }^{12}$ K. Żaczkiewicz-Zborska, op. cit.

${ }_{13}$ Por. uchwała SN z 15 II 1971 r., sygn. III CZP 33/70, OSN 1971, nr 4, poz. 59.

${ }^{14} \mathrm{Na}$ temat specyfiki odpowiedzialności wyznaniowych osób prawnych za czyny duchownych zob. E. Łętowska, Odpowiedzialność „za” księży-dyskusja ciągle niedokończona, w: Czynić postęp w prawie. Ksiega jubileuszowa dedykowana Profesor Birucie Lewaszkiewicz-Petrykowskiej, pod red. W. Robaczyńskiego, Łódź 2017, s. 295-309. 
Najwyższy odwołał się szeroko do Kodeksu Prawa Kanonicznego (KPK) z 1983 r. oraz, co znamienne i zasługujące na krytykę, do Ewangelii. Wskazuje to bowiem na pewną niesamodzielność argumentacyjną SN, na pomieszanie sfery świeckiej i sfery religijnej, które to obszary powinny być w myśl Konstytucji RP i ustawy o gwarancjach wolności sumienia i wyznania rozdzielone. Sąd zaś jest organem państwa świeckiego, neutralnego światopoglądowo. SN, ustalając, czy wyrządzenie szkody nastąpiło przy wykonywaniu czynności powierzonych sprawcy przez jego przełożonych, nie posłużył się wyraźnie kryterium zgodności celu powierzonych czynności przez zwierzchników z faktycznym celem działania sprawcy ${ }^{15}$. Zwrócił jednak uwagę, że pomoc okazana zwłaszcza początkowo ofierze przez sprawcę miała charakter ogólnoduszpasterski i mieściła się w zakresie celów zarówno całego pozwanego zgromadzenia zakonnego, jak i właściwego domu zakonnego. $W$ uzasadnieniu komentowanego wyroku zabrakło wszakże odniesienia do konkretnych celów zawartych $\mathrm{np}$. w regule pozwanego zgromadzenia zakonnego.

Trzeba zwrócić uwagę na fakt, że bycia osobą duchowną nie można ograniczać tylko do wykonywania funkcji religijnych w znaczeniu ścisłym, np. do odprawiania nabożeństw, przewodzenia modlitwie, prowadzenia katechezy czy udzielania sakramentów. Bycie księdzem, a zwłaszcza bycie osobą zakonna, to pewien stan, który rozciąga się na całość aktywności życiowej danej osoby. Zgodnie z nauczaniem Kościoła katolickiego kapłaństwo jest sakramentem, którego znamię jest nieusuwalne. Duchowny jest zobowiązany do dawania świadectwa głoszonym zasadom religijno-moralnym przez całe swoje życie. Status duchownego jest statusem szczególnym - wyróżnionym, a zarazem naznaczonym. Na to zwrócił uwagę w swoim orzeczeniu SN.

W uzasadnieniu analizowanego wyroku przekonująco wykazano, że gdyby sprawca nie był księdzem, a zwłaszcza gdyby nie pełnił funkcji katechety, nie doszłoby do wyrządzenia szkody ofierze-powódce. Sprawca nawiązał kontakt z ofiarą jako katecheta. Jako osoba duchowna wytworzył stan zaufania w stosunku do siebie po stronie ofiary i jej rodziców. Stan duchowny działał jako swoisty, fałszywy - jak się okazało, gwarant bezpieczeństwa. Pozwalał zakładać, że ze strony świętobliwej osoby nic

${ }^{15}$ Por.: M. Safian, Art. 430, w: Kodeks cywilny. Komentarz, t. 1, pod red. K. Pietrzykowskiego, Warszawa 1999, s. 1010; G. Bieniek, Art. 430, w: G. Bieniek i in., Komentarz do Kodeksu cywilnego. Ksiegga Trzecia. Zobowiazzania, t. 1, Warszawa 1996, s. 292; W. Borysiak, Art. 430, w: Kodeks cywilny. Komentarz, t. 2: Zobowiazania, pod red. K. Osajdy, Warszawa 2013, s. 562. 
złego dziecka spotkać nie mogło. W konsekwencji sprawca doprowadził do wytworzenia się stosunku zależności między nim a ofiara, co umożliwiło dokonanie czynów pedofilskich. W analizowanej sprawie przestępcze działania sprawcy skutkujące krzywdą ofiary-powódki pozostawały w integralnym związku z faktem, że był on osobą duchowną (zakonną). Gdyby nie ta okoliczność, nie mógłby on podjąć i rozwinąć szkodliwej działalności. W szczególności sprawca wykorzystywał swoje kontakty i znajomości w strukturach kościelnych oraz w środowisku katolików świeckich. Do zbliżeń z ofiarą miało dochodzić m.in. w budynkach kościelnych. Zawsze wówczas, co zauważył SN, występował jako osoba duchowna. Z takiej pozycji sprawca formułował także groźby pod adresem ofiary, gdy ta próbowała uwolnić się od niego. Szata duchowna dawała mu fałszywe poczucie prestiżu, wyższości, z czasem bezkarności, swoistego immunitetu. Życzliwość i pomoc okazywana ofierze pochodzącej z rodziny patologicznej mogła być oceniana przez postronnych jako praktykowanie cnót ewangelicznych. W praktyce jednak okazała się wstępem lub kamuflażem dla nadużyć seksualnych, które wyrządziły ofierze nieodwracalne szkody. Jak konkludował SN, sprawca wskutek nieprawidłowo wykonywanej czynności powierzonej, tj. fałszywie manifestując udzielenie powódce bezinteresownej pomocy, wykorzystał ją seksualnie i w ten sposób wyrządził jej szkodę, w skład której wchodzą również skutki związane z wywołanym rozstrojem zdrowia psychicznego ${ }^{16}$. W uzasadnieniu wyroku z 31 marca $2020 \mathrm{r}$. wykazano związek między działaniem sprawcy w ramach czynności powierzonych o charakterze duszpasterskim a szkodą wyrządzoną powódce. Może się jednak pojawić wątpliwość co do zgodności celów działania pozwanych instytucji kościelnych z ukrytym, przestępczym celem działania sprawcy. Owa kwestia nie została w uzasadnieniu wyroku dostatecznie jednoznacznie przesądzona ${ }^{17}$.

Sąd odstąpił od utrwalonego w orzecznictwie i doktrynie poglądu, że w świetle art. 430 k.c. sprawca może mieć tylko jednego zwierzchni$\mathrm{ka}^{18}$. Wyczerpująco i przekonująco wykazał, że w analizowanym przypadku sprawca podlegał zgodnie z prawem kanonicznym zarówno władzom wspomnianego zgromadzenia zakonnego, jak i przełożonemu

\footnotetext{
${ }^{16}$ Por. szerzej G. Bieniek, op. cit., s. 291-293.

${ }_{17}$ Por. inaczej E. Łętowska, Odpowiedzialność Kościoła za szkody wyrządzone przez księży, „Państwo i Prawo" 2015, z. 3, s. 17-18.

${ }^{18}$ Por. M. Wałachowska, Art. 430, w: Kodeks cywilny. Komentarz, t. 3: Zobowiązania. Część ogólna (art. 353-534), pod red. M. Habdas, M. Frasa, Warszawa 2018, s. 483.
} 
swego domu zakonnego. Ten ostatni wiedział o pomocy, jakiej sprawca udzielał ofierze-powódce. Oba te ośrodki kierownicze mogły skutecznie oddziaływać na zachowanie sprawcy i nie dopuścić do jego przestępczych działań, względnie je przerwać, o ile dopełniłyby prawidłowo obowiązku nadzoru. To jednak nie nastąpiło. W związku z tym ponoszą solidarną odpowiedzialność o charakterze cywilnym. Należy wszakże odnotować, co może budzić wątpliwości, że pozwane zostały zwierzchnie instytucje zakonne - Towarzystwo Chrystusowe dla Polonii Zagranicznej oraz odpowiedni dom zakonny - nie zaś osoby fizyczne będące przełożonymi sprawcy ${ }^{19}$. Stało się tak prawdopodobnie dlatego, że jako osoby zakonne wspomniani zwierzchnicy nie posiadają własnego majątku, z którego mogłyby być skutecznie egzekwowane zasądzone roszczenia. Stanowisko zajęte przez SN w sprawie odpowiedzialności zwierzchników sprawcy otwiera drogę do rozszerzenia zakresu podmiotowego odpowiedzialności w ramach zhierarchizowanych struktur występujących zwłaszcza w niektórych Kościołach chrześcijańskich ${ }^{20}$.

W uzasadnieniu wyroku SN wskazano na związek między brakiem prawidłowego nadzoru nad sprawca, i to nawet w sytuacji jego zachowań wyraźnie niecodziennych, wręcz kontrowersyjnych, a przestępczym procederem, który spowodował wyrządzenie szkody (krzywdy) ofierze-powódce. Tymczasem ustawodawca kościelny jest szczególnie wrażliwy na punkcie zachowania celibatu przez duchownych. Wskazuje na to Kan. 277 § 2 KPK, który głosi, że duchowni powinni odnosić się z należytą roztropnością do osób, do których uczęszczanie mogłoby narazić na niebezpieczeństwo ich obowiązek zachowania wstrzemięźliwości lub wywołać zgorszenie wiernych. Rodzi się pytanie, dlaczego władze zwierzchnie nie wywiązywały się prawidłowo z obowiązków nadzorczych wobec sprawcy. Nie można tego tłumaczyć tylko jego siła przekonywania czy umiejętnością maskowania się. Być może zawiódł przepływ informacji w strukturach zakonnych. A może zwyciężyła źle pojęta solidarność grupowa albo wystapił brak dostatecznej wrażliwości (czujności) na ewentualność wyrządzenia krzywdy osobie nieletniej. Jest to o tyle zdumiewające, że Kościół katolicki w swoim nauczaniu akcentuje znaczenie etyki seksualnej. Niektórzy krytycy zarzucają mu wręcz swoistą obsesję na punkcie seksualności człowieka. Mimo to

${ }^{19}$ Por. W. Borysiak, op. cit., s. 557.

${ }^{20}$ Zob. P. Borecki, Opinia prawna w sprawie wybranych aspektów ustroju hierarchicznego Kościoła katolickiego oraz statusu duchownych w świetle kodeksu prawa kanonicznego, „Przegląd Prawa Wyznaniowego" 2015, t. 7, s. 255-265. 
jednak zastrzeżeń przełożonych zakonnych nie wzbudziła zażyłość sprawcy z ofiarą.

W związku z odpowiedzialnością zwierzchników kościelnych za działania sprawcy nasuwa się pytanie mające nie tylko charakter zagadnienia akademickiego, ale potencjalnie także wymiar praktyczny, czy do odpowiedzialności cywilnej nie mogłaby być pociągnięta Stolica Apostolska jako najwyższy organ kierowniczy Kościoła katolickiego. Posiada ona zarazem osobowość prawną i dysponuje majątkiem na terenie Polski. Znajduje się w naszym kraju przedstawicielstwo dyplomatyczne Stolicy Apostolskiej. Należy zauważyć, że Stolica Apostolska nie jest państwem. Nie podlega zatem wyłączeniu spod jurysdykcji sądów polskich na podstawie immunitetu sądowego przysługującego państwom ${ }^{21}$. Jednocześnie papież zgodnie z Kan. 331 KPK posiada najwyższa, pełna, bezpośrednią i powszechną władzę zwyczajną w Kościele, którą może wykonywać zawsze w sposób nieskrępowany. Biskup Rzymu stoi na czele uniwersalnej międzynarodowej korporacji o charakterze wyznaniowym ${ }^{22}$. Bezpośredni charakter władzy papieskiej sprawia, że papież może ją sprawować wobec całego Kościoła powszechnego, wszystkich wiernych bez konieczności autoryzacji, zezwolenia czy licencji ordynariuszy miejscowych lub personalnych ${ }^{23}$. Podlega mu zatem każda osoba duchowna ${ }^{24}$. Jest wobec niego zobowiązana do subordynacji. Duchowni winni okazywać podporządkowanie jurysdykcyjne zwłaszcza w sprawach dyscypliny i prawa Kościoła ${ }^{25}$. Owa zależność wyraża się w wyeksponowanym przez Kodeks Prawa Kanonicznego z 1983 r. obowiązku okazywania szacunku i posłuszeństwa duchownego wobec papieża i własnego ordynariusza (Kan. 273). Papież swoje uprawnienia wobec duchownych realizuje za pośrednictwem właściwych dykasterii Kurii Rzymskiej; w szczególności jest to Kongregacja Duchowieństwa, ewentualnie również Kongregacja Instytutów Życia Konsekrowanego

${ }^{21}$ Zob. art. 1103(7) pkt 2 Ustawy z dnia 17 XI 1964 r. - Kodeks postępowania cywilnego (tekst jedn. Dz.U. 2020 r., poz. 1575).

${ }^{22}$ Por. J. Krukowski, Konkordaty współczesne. Doktryna. Teksty (1964-1994), Warszawa 1995, s. 37.

${ }^{23}$ J. Krukowski, Hierarchiczny ustrój Kościoła, w: J. Dyduch, W. Góralski, E. Górecki, J. Krukowski, M. Sitarz, Komentarz do Kodeksu Prawa Kanonicznego, t. II/1, Księga II: Lud Boży, pod red. J. Krukowskiego, Poznań 2005, s. 160.

${ }_{24}$ Por. W. Jakubowski, M. Solarczyk, Ustrój Kościoła Rzymskokatolickiego. Wybrane zagadnienia instytucjonalne, Warszawa 2002, s. 15.

${ }^{25}$ Codex Iuris Canonici. Kodeks Prawa Kanonicznego. Komentarz, pod red. P. Majera, Kraków 2011, s. 303. 
i Stowarzyszeń Życia Apostolskiego ${ }^{26}$. Wydaje się, że o ile teza o odpowiedzialności Stolicy Apostolskiej za pedofilskie czyny szeregowego duchownego na podstawie art. 429 lub 430 k.c. byłaby pewnym nadużyciem, to nie można takiej odpowiedzialności wykluczyć w przypadku, gdy czynów pedofilskich dopuszczaliby się przedstawiciele wyższego kleru: kardynałowie, biskupi, wyżsi przełożeni zakonni. Ich stosunek zależności wobec Stolicy Apostolskiej jest bowiem bezpośredni. Odpowiednio powyższe uwagi należy odnieść do procederu tzw. tuszowania pedofilii wśród duchowieństwa przez hierarchów kościelnych ${ }^{27}$.

\section{Funkcje zadośćuczynienia w ocenie Sądu Najwyższego}

W dalszej części uzasadnienia wyroku SN zwrócił uwagę na pozakompensacyjne funkcje zadośćuczynienia w rozpatrywanej sprawie. Chodzi o funkcję represyjną oraz - zwłaszcza - funkcję prewencyjną. Sądy niższych instancji skupiały się przede wszystkim na funkcji kompensacyjnej i represyjnej zadośćuczynienia.

Rozpatrując funkcję represyjną zadośćuczynienia, SN odwołał się do swych wcześniejszych orzeczeń z lat siedemdziesiątych i osiemdziesiątych XX w. Stanął na stanowisku, że zadośćuczynienie ma stanowić dla zobowiązanego sankcję stosowną do popełnionego czynu. Sankcja powinna być odczuwalna. Określając wysokość zadośćuczynienia, sąd powinien więc uwzględnić sytuację majątkową sprawcy. Na wysokość zadośćuczynienia ma też wpływ większe nasilenie winy. Ponadto, jak trafnie i sprawiedliwie skonstatował $\mathrm{SN}, \mathrm{w}$ ramach represyjnej funkcji zadośćuczynienia należy uwzględnić zachowanie sprawcy krzywdy po jej wyrządzeniu oraz to, czy sprawca podjął czynności mające na celu usunięcie skutków swojego działania. W związku z tym trzeba podkreślić, że w rozpatrywanej sprawie zarówno sprawca - osoba duchowna, jak i instytucje Kościoła katolickiego, z którymi był związany i którym

${ }^{26}$ Zob. W. Jakubowski, M. Solarczyk, op. cit., s. 80-82.

${ }^{27}$ Por. A. Głowacka, Odpowiedzialność osób prawnych Kościoła katolickiego za czyny niedozwolone, „Acta Erasmiana” 2015, t. 9, Varia II, s. 153, http://www.repozytorium.uni. wroc.pl/Content/65065/010_Glowacka_Aleksandra_Odpowiedzialnosc_osob_prawnych_Kosciola_katolickiego_za_czyny_niedozwolone.pdf(dostęp: 14 IX 2020). Zob. też Pedofilia w Kościele. „Watykan umożliwił swa postawa czyny pedofilii”, https:// prawo.money. pl/aktualnosci/wiadomosci/artykul/pedofilia;w;kosciele;watykan;umozliwil;swa;postawa;czyny;pedofilii,93,0,1472861.html (dostęp: 14 IX 2020). 
podlegał, w ogóle nie zainteresowały się losem ofiary. Pomoc i wsparcie ze strony instytucji kościelnych otrzymał natomiast sprawca.

Należy się zgodzić z przyjętymi przez Sąd Najwyższy przesłankami określenia wysokości zadośćuczynienia. W pełni zasadnie rzeczony organ uznał, że na wysokość zadośćuczynienia ma wpływ również rodzaj i charakter czynu niedozwolonego bezpośredniego sprawcy, w dodatku skierowany przeciwko dziecku, a także jego wina umyślna. Sprawca działał z wyjątkowo niskich pobudek. Z tej przyczyny rozmiaru krzywdy powódki nie można porównać ze sprawami, których zdecydowanie większy rozstrój zdrowia i uszczerbek poszkodowanego, skutkujący zasądzeniem wysokiego zadośćuczynienia, został wywołany z winy nieumyślnej.

Z kolei zadośćuczynienie w jego aspekcie prewencyjnym, jak trafnie podkreślił naczelny organ judykatury, ma na celu ochronę dzieci przed wykorzystywaniem seksualnym ze strony duchownych oraz zwrócenie na te zjawiska uwagi kościelnych osób prawnych. SN stwierdził, że wyrok sądowy ma oddziaływać na przyszłość nie tylko w stosunku do pozwanych (prewencja indywidualna), ale także w stosunku do innych osób prawnych i fizycznych, które ze względu na charakter i przedmiot prowadzonej działalności są zwierzchnikami powierzającymi na własny rachunek podwładnym czynności służbowe, których immanentną cechą jest osobisty kontakt z dziećmi i młodzieżą (prewencja ogólna) ${ }^{28}$. Sąd przyznał otwarcie, że orzeczona w stosunku do pozwanych dolegliwość finansowa ma na celu podjęcie właściwych środków zmierzających do bardziej starannego dobierania podwładnych, którzy mają wykonywać powierzone im tego rodzaju czynności, oraz do zapewnienia rzeczywistego i należytego nadzoru eliminującego lub ograniczającego do minimum wyrządzanie krzywdy dzieciom. W tym wyraża się ogólnospołeczne znaczenie komentowanego orzeczenia.

Sąd Najwyższy słusznie zaakcentował, że ochrona dzieci przed wykorzystywaniem seksualnym ma charakter intensywny i uniwersalny. Zwrócił uwagę, że Polska przyjęła na siebie zobowiązania prawnomiędzynarodowe wynikające z Konwencji o prawach dziecka z 1989 r. $^{29}$ Podkreślił trafnie, iż dla pozwanych - zgromadzenia zakonnego oraz jego domu zakonnego - troska o właściwy rozwój psychiczny i duchowy

${ }^{28}$ Zob. T. Królak, M. Przeciszewski, Mec. Królikowski: Kościót musi odrobićlekcje płynąca z przypadku chrystusowców, https://ekai.pl/mec-krolikowski-kosciol-musi-odrobic-lekcje-plynaca-z-przypadku-chrystusowcow/ (dostęp: 8 VII 2020).

${ }^{29}$ Dz.U. 1991 Nr 120, poz. 526. 
dzieci oraz ich ochrona przed krzywdą, której mogą niekiedy doświadczyć ze strony duchownych, powinna być szczególnie bliska ze względów ewangelicznych. To stanowisko wskazuje na charakterystyczny $\mathrm{w}$ komentowanym orzeczeniu trend do pośredniego uzasadniania stanowiska SN poprzez odwołanie do Biblii. Odwołania te są celne, stanowią dodatkowe wsparcie dla werdyktu Sądu, wskazują, że sprawca oraz pozwane kościelne osoby prawne nie respektowały standardów, których same powinny przestrzegać. Dowodzi to ich hipokryzji. Rodzi się jednak wątpliwość, czy orzecznictwo sądów świeckich w państwie niewyznaniowym, neutralnym w sprawach religii i przekonań, państwie, którego władze zgodnie z ustawą zasadniczą winny być bezstronne (neutralne) światopoglądowo, powinno zawierać stosunkowo częste odwołania do pierwiastków religijnych o proweniencji chrześcijańskiej.

Naczelny organ judykatury zasadnie poddał krytyce proces formacji sprawcy w pozwanym zgromadzeniu zakonnym oraz nadzór nad duchownym ze strony jego przełożonych. Zwrócono uwagę, iż sprawca, pomimo że wykazywał skłonności pedofilskie podczas pobytu w seminarium duchownym, został dopuszczony do święceń i do pracy z dziećmi. Nie podjęto w stosunku do niego czynności mających wykluczyć przymioty stanowiące przeciwwskazania do pracy z najmłodszymi. Sąd Najwyższy wytknął stronie kościelnej, że Kodeks Prawa Kanonicznego wśród bezwzględnych przeszkód dopuszczenia do święceń nie wymienia skłonności pedofilskich kandydata do stanu duchownego. Zwrócono także uwagę, że dopuszczenie się przez duchownego wykorzystywania seksualnego małoletniego poniżej 16. roku życia w świetle art. $1395 \S 2$ KPK nie powoduje automatycznie zastosowania kary wydalenia ze stanu duchownego. Sąd, konkludując, wskazał, że sprawdzanie duchownych pod kątem wykluczenia lub co najmniej zminimalizowania skłonności pedofilskich powinno być bardziej wnikliwe, niż to faktycznie miało miejsce. Wynika z tego, że w praktyce działania Kościoła wewnętrzne standardy ochrony dzieci przed czynami pedofilskimi ze strony osób duchownych do niedawna nie były wysokie.

Należy jednak zwrócić uwagę, że Sąd Najwyższy, respektując konstytucyjną (art. 25 ust. 3) i konkordatową (art. 1) zasadę poszanowania niezależności i autonomii Kościoła w swoim zakresie ${ }^{30}$, nie wdał się w generalną krytykę systemu formacji kandydatów do stanu kapłańskiego

${ }^{30}$ Zob. szerzej m.in. W. Góralski, A. Pieńdyk, Zasada niezależności i autonomii Państwa i Kościoła w Konkordacie polskim z 1993 roku, Warszawa 2000, s. 11-35. 
w seminariach oraz w formułowanie jakichś dyrektyw w tym zakresie. Te zagadnienia jako wewnętrzna sprawa Kościoła winny być pozostawione wyłącznie w jego gestii. Można jednak przypuszczać, że ewentualne ukształtowanie się linii orzeczniczej zapoczątkowanej przez omawiany wyrok stanie się jednym z czynników moderujących proces doboru i kształtowania przyszłych duchownych. Potrzebę zmian w zakresie formacji kandydatów do kapłaństwa już dostrzegła Konferencja Episkopatu Polski, w październiku 2019 r. przyjmując projekt dokumentu pt. „Droga formacji prezbiterów w Polsce. Ratio institutionis sacerdotalis pro Polonia" ${ }^{\prime 1}$. Jednym z celów dokumentu jest uwrażliwienie seminarzystów na problem wykorzystywania seksualnego nieletnich.

\section{Kwestia bezstronności składu orzekającego}

Sprawa związana ze skargą kasacyjną Towarzystwa Chrystusowego dla Polonii Zagranicznej oraz jego odpowiedniego domu zakonnego wzbudziła duże zainteresowanie opinii publicznej. Ze względu na dobro ofiary-powódki domagano się bezskutecznie od pozwanych wycofania skargi kasacyjnej ${ }^{32}$. Adresaci petycji odpowiedzieli na nią odmownie ${ }^{33}$. Pod kompleksem gmachów Sądu Najwyższego miały nawet miejsce demonstracje w obronie interesów pokrzywdzonej. Następnie uwagę przykuł skład pierwotnie wyznaczony do rozpatrzenia sprawy. Znalazły się w nim bowiem osoby związane swoimi interesami zawodowymi z Kościołem katolickim ${ }^{34}$. Rodziło to uzasadnione obawy co do bezstronności składu orzekającego w sprawie II CSK 124/19. Pełnomocnik

${ }^{31}$ Omówienie szczegółowe wspomnianego dokumentu zob. https://ekai.pl/episkopat-przyjal-nowe-zasady-formacji-w-seminariach-duchownych/ (dostęp: 3 VIII 2020).

32 Petycję w tej sprawie podpisało 16000 osób (KAI/kk, 16 tys. osób prosi chrystusowców o wycofanie skargi kasacyjnej, https://deon.pl/kosciol/16-tys-osob-prosi-chrystusowcow-o-wycofanie-skargi-kasacyjnej,647622, dostęp: 10 VII 2020).

${ }^{33}$ Zob. przyp. 6.

${ }^{34}$ Pierwotnie sędzią sprawozdawcą została wyznaczona Joanna Misztal-Konecka, będąca profesorem Katolickiego Uniwersytetu Lubelskiego; kolejnym sędzią miała być Beata Janiszewska, która uprzednio wydała korzystny wyrok w sprawie zasiedzenia na rzecz jednej z parafii, a także Marcin Krajewski, który w przeszłości reprezentował Kościół katolicki w sprawie o zadośćuczynienie na rzecz ofiary księdza pedofila (K. Siałkowski, P. Żytnicki, Chrystusowcy złożyli kasację w sprawie $1 \mathrm{mln}$ zł dla ofiary księdza gwałciciela. Będzie zmiana składu sędziowskiego?, https://warszawa.wyborcza.pl/warszawa/7,54420,25390308,chrystusowcy-zlozyli-kasacje-w-sprawie-1-mln-zl-dla-ofiaryksiedza.html, dostęp: 10 VII 2020). 
powódki wniósł o zmianę składu orzekającego. Ostatecznie przed przystąpieniem do merytorycznego rozpatrzenia sprawy nastąpiła bezprecedensowa zmiana całego składu orzekającego ${ }^{35}$. Prawdopodobnie przesądziły tu zarzuty o charakterze wyznaniowym. Być może wzięto pod uwagę także zarzuty o charakterze ustrojowym, tzn. powołanie sędziów SN wchodzących pierwotnie w skład składu orzekającego przez tzw. nową Krajową Radę Sądownictwa - organ ustanowiony według klucza politycznego.

Postawa SN, wyrażająca troskę o zagwarantowanie wysokich standardów bezstronności, pozytywnie kontrastuje z postępowaniem Trybunału Konstytucyjnego, który rozpatrując sprawę mającą znaczenie dla żywotnych interesów Kościoła katolickiego, odrzucił wniosek o wyłączenie ze składów orzekających sędziego sprawozdawcy powiązanego, zwłaszcza zawodowo, z Kościołem katolickim ${ }^{36}$. Na skutek tego m.in. nie można orzecznictwa TK uznać za spełniające konstytucyjny wymóg bezstronności światopoglądowej ${ }^{37}$.

Rodzą się jednak pewne wątpliwości co do zachowania na tle analizowanej sprawy bezstronności światopoglądowej przez organy sądowe w innym wymiarze. Sąd Najwyższy, jak się wydaje, w istocie podzielił pogląd Sądu Okręgowego, że na rozmiar krzywdy powódki wpływa również jej całkowita rezygnacja z udziału w życiu Kościoła, podczas gdy przed traumatycznymi zdarzeniami była osobą wierzącą i praktykującą. Przez działania sprawcy (księdza zakonnego) oraz postawę jego zgromadzenia zakonnego, które w ogóle nie zainteresowało się losem ofiary czynów pedofilskich zakonnika, powódka straciła wiarę i została w konsekwencji pozbawiona korzyści niematerialnych płynących z tej sfery życia człowieka, zwłaszcza w chwilach trudnych. To stanowisko wymaga polemiki. Wydaje się, że zgodnie z konstytucyjną zasadą bezstronności władz publicznych w sprawach przekonań religijnych, światopoglądowych i filozoficznych (art. 25 ust. 2 Konstytucji RP) zwłaszcza organy wymiaru sprawiedliwości winny powstrzymać się od wartościowania światopoglądów, szczególnie gdy dotyczy to

${ }^{35}$ Zob. Zaskakujaca decyzja SN w sprawie kasacji Chrystusowców, https://rebeliantka. neon24.pl/post/152519,zaskakujaca-decyzja-sn-w-sprawie-kasacji-chrystusowcow, dostęp: 10 VII 2020).

${ }^{36}$ Zob. postanowienie TK z dnia 31 I 2011 r., sygn. K 3/09, OTK ZU /2011, nr 1A, poz. 5.

${ }^{37}$ Por. art. 25 ust. 2 Konstytucji RP. Szerzej W. Brzozowski, Bezstronność światopogladowa władz publicznych w Konstytucji RP, Warszawa 2011, s. 19-239. 
uczestników postępowania. Nie powinny dokonywać nawet pośrednio, w państwie świeckim, neutralnym w sprawach religii i przekonań ${ }^{38}$, aprecjacji światopoglądu fideistycznego. Póki co Rzeczpospolita Polska nie jest jeszcze formalnie państwem wyznaniowym, którego organy wymiaru sprawiedliwości miałyby sankcjonować przyczynienie się do utraty wiary religijnej przez obywateli. To zakrawałoby wręcz na orwellowską myślozbrodnię. $Z$ wartościowaniem światopoglądów przez władze publiczne, tym razem na niekorzyść światopoglądu religijnego, mieliśmy do czynienia w Polsce Ludowej przed 1989 r. Był to okres rządów partii komunistycznej, lansującej metodami administracyjnymi światopogląd ateistyczny ${ }^{39}$. Sfera przekonań światopoglądowych, wiary czy nie-wiary, winna pozostać domeną prywatności jednostki. Owa domena powinna znajdować się w ogóle poza obszarem zainteresowań władz publicznych, zwłaszcza sądów. Czytelnie wskazuje na to art. 53 ust. 7 Konstytucji RP, zabraniając organom władz publicznych obowiązywania kogokolwiek do ujawnienia swojego światopoglądu, przekonań religijnych lub wyznania. Przedkładanie przez sądy światopoglądu fideistycznego ponad inne rodzaje światopoglądów nie znajduje uzasadnienia w Konstytucji, która wyraźnie rozróżniając obywateli wierzących w Boga, jak i niepodzielających tej wiary, nie wartościuje ich, lecz uznaje za równych w prawach i obowiązkach wobec dobra wspólnego - Polski. W świetle konstytucyjnej preambuły osób niewierzących nie można uważać za nihilistów, za osoby niemoralne. Posiadają one własny system wartości, nie gorszy od systemu wartości o charakterze religijnym.

Stanowisko organów wymiaru sprawiedliwości w sprawie utraty wiary religijnej przez powódkę jest dyskusyjne także z psychologicznego punktu widzenia. Wiara nie zawsze jest źródłem oparcia dla człowieka. Niejednokrotnie, zwłaszcza u osób wrażliwych, wywołuje przeżycia, a nawet stany negatywne - poczucie winy, stany lękowe czy nerwicowe, szczególnie na tle obaw przed złem osobowym czy karą wieczną. Wiara religijna może sprzyjać rozwojowi osobowości bierno-zależnej. Oczekiwanie na sprawiedliwość w wymiarze transcendentalnym może osłabić wolę poszkodowanej jednostki w dochodzeniu należnych jej praw w życiu doczesnym. Wiara religijna może też ułatwiać oddziaływanie osób o charakterze autorytarnym, działających w swoich partykularnych interesach. Należy zauważyć, że do czasów Soboru Watykańskiego II

${ }^{38}$ Zob. art. 10 ust. 1 Ustawy z dnia 17 V 1989 r. o gwarancjach wolności sumienia i wyznania (tekst jedn. Dz.U. 2017, poz. 1153).

${ }^{39}$ Por. M. Pietrzak, Prawo wyznaniowe, Warszawa 2013, s. 162-165. 
i papieży posoborowych światopogląd katolicki miał charakter wyraźnie opresyjny. Zmiana światopoglądu religijnego na niefideistyczny może być oceniana jako zjawisko pozytywne, świadczące o intelektualnym i psychicznym wyemancypowaniu się jednostki spod wpływów autorytarnych osób czy instytucji. Rzeczony proces może być uznany za dowód osiągnięcia przez człowieka duchowej dojrzałości, przejaw wzięcia pełnej odpowiedzialności za własne życie.

W rozpatrywanym przypadku religijny (katolicki) światopogląd powódki przyczynił się do jej nieszczęść. Jako wierząca uczęszczała na lekcje religii, podczas których poznała sprawcę. Uformowany w niej przez wychowanie religijne autorytet osób duchownych osłabił jej krytycyzm wobec działań sprawcy. Legł u podstaw zaufania do duchownego oraz instytucji kościelnych. Doprowadził do popadnięcia w stan zależności, który umożliwił sprawcy dokonywanie czynów pedofilskich. Paraliżował wolę przeciwstawienia się złu, którego sprawcą był duchowny. Można zaryzykować stanowisko, że wiara religijna powódki i jej najbliższych doprowadziła do nadmiernego zaufania wobec sprawcy będącego osobą duchowną. Uśpiła ich czujność i krytycyzm w czasie, kiedy nie było jeszcze za późno. Zaowocowała fatalnie w postaci gloryfikacji sprawcy i podporządkowania się mu. Przy tym można przypuszczać, że dla poszkodowanej źródłem dodatkowych negatywnych przeżyć, takich jak poczucie zawodu, rozczarowanie, żal czy irytacja, był zasadniczy kontrast między założeniami doktryny religijno-moralnej głoszonej oficjalnie przez Kościół katolicki a zachowaniem sprawcy oraz instytucji zakonnych, którym on podlegał. Wiara religijna poszkodowanej doprowadziła do powstania u niej oczekiwań i nadziei, które w zderzeniu $\mathrm{z}$ realiami okazały się nieuprawnione.

W sumie należy stwierdzić, że orzeczenia sądowe nie są właściwym miejscem do roztrząsania kwestii wiary religijnej poszczególnych osób. Jest to bowiem przeżycie głęboko osobiste, wręcz intymne, wymykające się racjonalnym i obiektywnym ocenom. Jako takie stanowi domenę prywatności, w którą organy władzy publicznej wkraczać nie powinny, chyba że jest to władza totalitarna.

\section{Podsumowanie}

Wyrok z 31 marca 2020 r. trzeba ocenić jako odważny i sprawiedliwy, pomimo pewnych zastrzeżeń zwłaszcza co do zachowania przez Sąd 
Najwyższy bezstronności (neutralności) światopoglądowej. Ma on szanse wyznaczyć kierunek orzecznictwa sądowego w sprawach odpowiedzialności wyznaniowych osób prawnych za czyny pedofilskie osób duchownych działających pod ich nadzorem. Uzasadnienie komentowanego orzeczenia jest, co zrozumiałe, krytyczne wobec sprawcy oraz zwierzchnich wobec niego kościelnych osób prawnych, a także niekiedy wobec postanowień Kodeksu Prawa Kanonicznego. Należy wszakże podkreślić, że wyrok nie jest "aktem oskarżenia” wobec Kościoła katolickiego jako takiego, czy tym bardziej wobec religii. Rzeczonej antyklerykalnej pokusie Sąd Najwyższy oparł się skutecznie. Dlatego m.in. może ten wyrok oddziaływać szerzej, dostarczając wzorców orzeczniczych w sprawach nadużyć seksualnych, których miałyby się dopuścić osoby podległe innym instytucjom niż wyznaniowe osoby prawne, np. nauczyciele, trenerzy klubów sportowych, lekarze itp. Trzeba zaznaczyć, że w omawianym wyroku Sąd w istocie rzeczy szeroko ujmuje zasady odpowiedzialności cywilnej od strony przedmiotowej i podmiotowej na podstawie art. 430 k.c. $W$ związku z tym wyrok otwiera ofiarom tego rodzaju czynów perspektywę sprawiedliwego zadośćuczynienia w konfrontacji z wpływowymi, skupionymi na własnych interesach i zdehumanizowanymi instytucjami kościelnymi. Wyrok przyczyni się zapewne do zwiększenia czujności w nadzorze nad swoim personelem ze strony instytucji podejmujących pracę z dziećmi i młodzieżą.

Wciąż bardzo wiele zależy od determinacji i odwagi ofiar czynów pedofilskich osób duchownych. W niesprzyjającej im sytuacji ogólnopolitycznej w kraju, wyrażającej się w rządach partii określającej się jako katolicka, inspirowanej przez środowiska ultrakonserwatywne, poszkodowani moga poszukiwać wsparcia w laickich środkach masowego przekazu oraz w niezawisłym sądownictwie, sprawowanym przez bezstronna, nonkonformistyczną kadrę sędziowską. Bardzo wiele zależy właśnie od sędziów, od tego, czy będą zdolni: dostrzec dramat ofiar pedofilii, przekroczyć ograniczenia mentalne będące następstwem oddziaływania światopoglądu fideistycznego (katolickiego), oprzeć się presji otoczenia religijnego, a zwłaszcza oczekiwaniom przełożonych, w tym kierownictwa resortu sprawiedliwości. Obecna sytuacja społeczno-polityczna w Polsce, przejawiająca się zanikiem rozdziału państwa i Kościoła oraz ewidentnym odrzuceniem zasady bezstronności (neutralności) światopoglądowej władz publicznych, stwarza realne zagrożenie dla bezstronnego rozpatrzenia spraw sądowych, w które zaangażowane są instytucje kościelne lub osoby duchowne. Nasuwa 
się w związku z tym wniosek, że wymienione wyżej zasady stosunków wyznaniowych to nie tylko gwarancje wolności sumienia i wyznania, ale także pośrednio gwarancje niezawisłości sędziowskiej i niezależności sądów. Sędziowie, rozpatrując sprawy z udziałem pierwiastka religijnego, czy szerzej - światopoglądowego, powinni przyjąć, niezależnie od własnych przekonań w sprawach religijnych, postawę metodycznego agnostycyzmu. Co za tym idzie, osoby duchowne i instytucje wyznaniowe winny być $w$ praktyce traktowane na równi $z$ innymi podmiotami prawa niemającymi znamion konfesyjnych. Sąd Najwyższy w rozpatrywanej sprawie dał wyraz postawie, która może stać się wzorcem dla sądów niższych.

Pewne nadzieje można pokładać ewentualnie w międzynarodowych organach ochrony wolności i praw człowieka - Europejskim Trybunale Praw Człowieka ${ }^{40}$ czy Komitecie Praw Człowieka ONZ. Należy mieć jednak świadomość, że generalnie rzecz ujmując, postępowanie przed instytucjami międzynarodowymi jest czasochłonne, a jego wynik niepewny.

\author{
RESPONSIBILITY OF CHURCH LEGAL ENTITIES \\ FOR THE ACTIONS OF A PEDOPHILE CLERGYMAN - \\ A JUDGMENT AS A PRECEDENT. \\ COMMENTS ON THE JUDGMENT OF THE SUPREME COURT \\ OF MARCH 31, 2020, FILE REF. NO. II CSK 124/19
}

\title{
S u m m a r y
}

The judgment of March 31, 2020, file ref. II CSK 124/19, has great social and legal significance. It is the first Supreme Court ruling concerning the civil liability of church legal entities for pedophilic acts committed by a clergyman. The Supreme Court shared the view of the Court of Appeal accepting the liability of church legal persons in the light of all the facts of the case of Art. 430 of the Civil Code (culpability in supervision). However, it convincingly distanced itself from the position of the District Court (court of first instance) that liability under Art. 429 of the Civil Code (culpability in choice) should be taken into consideration.

In the justification of the judgment, the Supreme Court conducted a thorough analysis of the premises for the civil liability of church legal persons for the activities of a religious person subordinate to them. In particular, it stated that if the perpetrator acts for personal gain and the performance of the official activity enables him to cause damage, the superior cannot effectively raise the objection

${ }^{40}$ Zob. K. Warecka, Kto odpowie za księdza pedofila. Uwagi na tle wyroku Wielkiej izby ETPC $z$ dnia 28 stycznia 2014 r., 35810/09 (O'Keefe), LEX/el. 2019. 
that the subordinate caused said damage only in the performance of the entrusted tasks. Thus, the Supreme Court upheld the interpretation of Art. 430 of the Civil Code, assuming the liability of legal persons for damage caused by a subordinate. It distinctly applied this liability to church legal entities.

When appointing the adjudication panel of the Supreme Court, impartiality was preserved. On the other hand, doubts are raised regarding the Court's neutrality in terms of world-view in some parts of its judgment justification. The judgment of March 31, 2020 must be assessed as brave and just. It has the chance to set the course of judicial decisions in matters of the liability of religious legal persons for pedophilic acts committed by clergy acting under their supervision. The justification of the judgment is understandably critical towards the perpetrator and church legal persons superior to him, and also sometimes towards the provisions of the Code of Canon Law. It should be emphasized, however, that the judgment is not an "indictment" against the Catholic Church as such, and even less so against religion.

Keywords: pedophilia - the Catholic Church - the Supreme Court - compensation - the Holy See

\section{LITERATURA}

Bez odszkodowań dla ofiar księży pedofilów, https://www.tvp.info/6740983/informacje/ polska/bez-odszkodowan-dla-ofiar-ksiezy-pedofilow/ (dostęp: 8 VII 2020).

Bieniek G., Art. 430, [w:] G. Bieniek i in., Komentarz do Kodeksu cywilnego. Ksiega Trzecia. Zobowiazania, t. 1, Warszawa 1996.

Borecki P., Opinia prawna w sprawie wybranych aspektów ustroju hierarchicznego Kościoła katolickiego oraz statusu duchownych w świetle kodeksu prawa kanonicznego, „Przegląd Prawa Wyznaniowego" 2015, t. 7.

Borysiak W., Art. 430, w: Kodeks cywilny. Komentarz, t. 2: Zobowiazania, pod red. K. Osajdy, Warszawa 2013.

Brzozowski W., Bezstronność światopoglądowa władz publicznych w Konstytucji RP, Warszawa 2011.

Cieśla Ł., Jest wniosek o przeszukanie poznańskiej kurii. W sprawie molestowania i gwałtów na bytym ministrancie z Chodzieży, "Gazeta Pomorska" 2020, nr 13.

Codex Iuris Canonici. Kodeks Prawa Kanonicznego. Komentarz, pod red. P. Majera, Kraków 2011.

Głowacka A., Odpowiedzialność osób prawnych Kościoła katolickiego za czyny niedozwolone, „Acta Erasmiana” 2015, t. 9, Varia II, http://www.repozytorium. uni.wroc.pl/Content/65065/010_Glowacka_Aleksandra_Odpowiedzialnosc_osob_prawnych_Kosciola_katolickiego_za_czyny_niedozwolone.pdf (dostęp: 14 IX 2020).

Góralski W., Pieńdyk A., Zasada niezależności i autonomii Państwa i Kościoła w Konkordacie polskim z 1993 roku, Warszawa 2000. 
Jakubowski W., Solarczyk M., Ustrój Kościoła Rzymskokatolickiego. Wybrane zagadnienia instytucjonalne, Warszawa 2002.

KAI, Chrystusowcy odpowiadaja na petycje w sprawie wycofania skargi kasacyjnej, https:// ekai.pl/chrystusowcy-odpowiadaja-na-petycje-w-sprawie-wycofania-skargi-kasacyjnej/ (dostęp: 10 VII 2020).

Klauziński S., Dziuba, Orszulik, Nycz i inni. Siedmiu biskupów, którzy tuszowali przypadki pedofilii.Śledztwa OKO.press, https://oko.press/biskupi-ktorzy-tuszowali-pedofilie-w-kosciele/ (dostęp: 8 VII 2020).

Krukowski J., Hierarchiczny ustrój Kościoła, w: J. Dyduch, W. Góralski, E. Górecki, J. Krukowski, M. Sitarz, Komentarz do Kodeksu Prawa Kanonicznego, t. II/1, Księga II: Lud Boży, pod red. J. Krukowskiego, Poznań 2005.

Krukowski J., Konkordaty wspótczesne. Doktryna. Teksty (1964-1994), Warszawa 1995.

Łętowska E., Odpowiedzialność Kościoła za szkody wyrządzone przez księży, „Państwo i Prawo" 2015, z. 3.

Łętowska E., Odpowiedzialność „za” księży - dyskusja ciagle niedokończona, w: Czynić postęp w prawie. Księga jubileuszowa dedykowana Profesor Birucie Lewaszkiewicz-Petrykowskiej, pod red. W. Robaczyńskiego, Łódź 2017.

ŁK, Abp Gądecki nie wydał dokumentów prokuraturze ws. Janiaka. Teraz będzie wizytatorem w kaliskim seminarium, https://wiadomości.gazeta.pl/7,114883,26082055,abp-gadecki-nie-wydal-dokumentow-prokuraturze-ws-janiaka-teraz.htm\#do_ w46\&do_a286\&s=BoxNewsLink (dostęp: 1 VII 2020).

Nesterowicz M., Odpowiedzialność cywilna Kościoła katolickiego za molestowanie małoletnich przez księży (prawo USA i prawo polskie), „Przegląd Sądowy” 2014, nr 1.

Pedofilia w Kościele. "Watykan umożliwił swa postawa czyny pedofilii”, https:// prawo.money.pl/aktualnosci/wiadomosci/artykul/pedofilia;w;kosciele;watykan;umozliwil;swa;postawa;czyny;pedofilii,93,0,1472861.html (dostęp: 14 IX 2020).

Pietrzak M., Prawo wyznaniowe, Warszawa 2013.

Safian M., Art. 430, w: Kodeks cywilny. Komentarz, t. 1, pod red. K. Pietrzykowskiego, Warszawa 1999.

Siałkowski K., Żytnicki P., Chrystusowcy złożyli kasację w sprawie $1 \mathrm{mln}$ zł dla ofiary księdza gwałciciela. Będzie zmiana składu sędziowskiego?, https://warszawa. wyborcza.pl/warszawa/7,54420,25390308,chrystusowcy-zlozyli-kasacje-w-sprawie-1-mln-zl-dla-ofiary-ksiedza.html (dostęp: 10 VII 2020).

Sieczych A., Odpowiedzialność odszkodowawcza związków wyznaniowych za przestępstwa seksualne duchownych w USA i w Polsce (casus Kościoła katolickiego), „Państwo i Prawo" 2017, z. 1.

Stanowisko Konferencji Episkopatu Polski w sprawie wykorzystywania seksualnego osób małoletnich przez niektórych duchownych, Jasna Góra, 19 XI 2018 r., https:// episkopat.pl/stanowisko-konferencji-episkopatu-polski-w-sprawie-wykorzystywania-seksualnego-osob-maloletnich-przez-niektorych-duchownych (dostęp: 8 VII 2020).

Wałachowska M., Art. 430, w: Kodeks cywilny. Komentarz, t. 3: Zobowiązania. Część ogólna (art. 353-534), pod red. M. Habdas, M. Frasa, Warszawa 2018.

Warecka K., Kto odpowie za księdza pedofila. Uwagi na tle wyroku Wielkiej izby ETPC $z$ dnia 28 stycznia 2014 r., 35810/09 (O'Keefe), LEX/el. 2019. 
Wójcik M., Biskupi, którzy kryli księży pedofilów [RAPORT], https://wyborcza.pl/duzyformat/7,127290,24884600,biskupi-ktorzy-kryli-ksiezy-pedofilow-raport. html (dostęp: 8 VII 2020).

Zalewski D., PAP, Bez odszkodowań dla ofiar pedofilii w polskim Kościele - dokument episkopatu, http://wiadomości.gazeta.pl/wiadomości/1.114883.11342994,Bez_odszkodowań_dla_ofiar_pedofilii_w_polskim_Kosciele.htm (dostęp: 1 VII 2020).

Zaskakujaca decyzja SN w sprawie kasacji Chrystusowców, https://rebeliantka.neon24. pl/post/152519,zaskakujaca-decyzja-sn-w-sprawie-kasacji-chrystusowcow (dostęp: 10 VII 2020).

Żaczkiewicz-Zborska K., SN: Zakon jako zwierzchnik księdza zapłaci zadośćuczynienie ofierze, https://www.prawo.pl/zadoscuczynienie-za-przestepstwo-księdza-zaplaci-zakon (dostęp: 22 VI 2020). 